\title{
TEACHING STRATEGIES TO RAISE AWARENESS OF NON-COMMUNICABLE DISEASES IN SECONDARY SCHOOLS IN BRUNEI DARUSSALAM
}

\author{
Noormah Azrayati Haji Mohammad Noor and Jainatul Halida Jaidin \\ Sekolah Menengah Berakas, Ministry of Education, Brunei Darussalam, Brunei \\ Sultan Hassanal Bolkiah Institute of Education, Universiti Brunei Darussalam, Brunei
}

\begin{abstract}
To date, non-communicable diseases (NCDs) remain the leading cause of disability and death in most countries, including Brunei Darussalam. As such, various strategies to improve health literacy have been introduced and carried out by both government and non-government agencies throughout the country. One of the on-going strategies is to raise awareness of NCDs among secondary school students through a subject called Food and Nutrition. This paper documents the teaching strategies used by five exemplary Food and Nutrition (FN) teachers in Brunei Darussalam. The aims of this study were to analyse and identify strategies as well as techniques that teachers could use to help students practice healthy lifestyle behaviours. A discussion on the extent to which these teaching strategies were effective in delivering important messages about NCDs is also presented. This study adopted a qualitative approach to research, wherein data were collected mainly through a series of lesson observations. In addition, analysis of teachers' lesson plans and students' work were used to obtain richer data. A total of five FN teachers and twenty-five students participated in the study. Overall, all teachers in the study preferred to use teacher-centred teaching strategies and very few teachers made the effort to incorporate student-centred teaching strategies in their lessons. However, it was found that the students were more engaged in lessons that provided opportunities for experiential and collaborative learning. The study makes a strong recommendation for student-centred teaching strategies in promoting healthy lifestyle behaviours among secondary school students. The findings of this study are useful to FN teachers, researchers and policy-makers. The findings serve as precursors to further research and decision-making.
\end{abstract}

Keywords: Food and Nutrition, Non-Communicable Diseases, Secondary Schools, Teaching Strategies

\section{Introduction}

In Brunei Darussalam's education system, Food and Nutrition (FN) is offered as an option subject under a broader subject area called the Technology Learning Area. FN is offered to Year 9, Year 10, and Year 11 students undergoing the General Science Programme, General Programme, and Applied Programme (Ministry of Education, 2013). Lack of knowledge on nutrition and good dietary habits, as well as lack of physical activity could prompt non-communicable diseases (NCDs).

NCDs are the main cause of death and disabilties in most countries around the world (Hawkes, 2013). Factors such as high blood pressure, high concentrations of serum cholesterol, tobacco smoking, unhealthy eating habits, overweight or obesity, and physical inactivity were found to be the main risk factors of NCDs (Musaiger \& Al-Hazzaa, 2012). Al-Nohair (2014) stated that factors such as international fast food chains, easy access to cars, increased popularity of processed food, and lack of exercise had contributed to dramatic increase in obesity in Gulf countries. Similarly, Brunei is not an exception. The rapid development of fast-food outlets and increased sedentary lifestyles had also shown adverse impact on most Bruneians especially among children and adolescents. According to Brunei Darussalam's Ministry of Health (2013), it was estimated that in 2012, 50.8\% males and $54.4 \%$ females died prematurely due to NCDs. In $2008,48.8 \%$ males and $38.3 \%$ females died 
prematurely from NCDs (Ministry of Health, 2013). These data suggest a significant increase in the number of deaths caused by NCDs. The top five leading causes of deaths according to a document on The Leading Causes of Deaths in Brunei (2008-2012) were cancers, heart diseases including acute rheumatic fever, diabetes mellitus, cerebrovascular diseases, chronic bronchitis and unspecified emphysema and asthma.

The Knowledge Convention Report (2012) highlighted that, 12.3\% of Bruneian students were obese in 2008. The statistic increased in 2010 by $1.2 \%$. In another study in 2011 involving 30,000 students, the issue of obesity among Bruneian school children was also highlighted. It was found that $30 \%$ of the participants were overweight, which was an increase of $1.7 \%$ from the previous year. The increase in the number of overweight and obese children is indeed a major concern, because in small countries like Brunei Darussalam, 10\% represents a significant proportion of the total population. Moreover, research has found that obesity at a young age is likely to persist into adulthood, which could lead to other chronic diseases (Güngör, 2014).

It is therefore important to raise awareness of factors leading to NCDs through education. Researchers such as Carraway-Stage, Henson, Dipper, Spangler, Ash, and Goodell (2014) argue that education through nutrition teaches students to make healthier choices of food, food preparation and safety. These researchers also found that in order to properly scaffold the teaching and learning of FN in schools, a number of aspects need to be taken into consideration, such as the teachers' competencies, time and resources available. Teaching nutrition using suitable and effective strategies can produce long term benefits to an individual and the population in general. According to Tull (1996), FN is the study of nutrients and their relationships with food and living things. The term nutrition refers to the study of food and its relation to health. Researchers such as Ball, Hughes and Leverin (2010) define nutrition as a foundation for basic treatment, health care, and health information in the $21^{\text {st }}$ Century. The definition is similar to those outlined by the National Public Health Partnership (2001), Strategic Inter-Governmental Nutrition Alliance (2001) and World Health Organisation (2003). Knowing about nutrition or nutrition education plays a critical part in promoting health throughout life, particularly in preventing and managing chronic diseases.

The FN curriculum in Brunei Darussalam's education system seeks to address challenging issues such as unhealthy diets, processed food, physical inactivity, and promote healthy lifestyle behaviours that include making the right food choices and planning meals. It is hoped that the topics taught in FN would educate and encourage students to lead a healthier lifestyle, and ultimately, reduce the major risk factors for NCDs. It is also important to note that healthy living requires a permanent lifestyle change and successful lifestyle change needs to start as early in life as possible. Researchers such as Denman (1999), Drummond (2010), and Singura (2013) suggest that, schools and classrooms are the best learning environments to begin long-term behavior change as students spend most of their time in schools. For example, students in Brunei Darussalam spend between six to nine hours (this includes attending religious classes in the afternoon) a day in schools. Equally significant in long-term behavior change is the strategies used by teachers to raise awareness of NCDs and introduce the benefits of practicing healthy lifestyle behaviours (Sovyanhadi \& Cort, 2004). Accordingly, it is important to observe, record and analyse the kinds of teaching strategies FN teachers use to discuss nutrition and practice healthy lifestyle behaviours. Such analysis will serve as a baseline data for further investigations on effective teaching strategies for FN, and in so doing, creates a resource bank of FN teaching strategies.

This paper outlines various strategies and techniques used by a group of five exemplary FN teachers in Brunei Darussalam. The aim is to provide an insight into ways in which curricular modifications can be made to address issues pertaining to NCDs. For example, findings of this study could suggest the implementation of practical strategies to counter NCDs in a systemic manner. However, the findings of this study are not intended for generalization. Rather, the findings are aimed at providing insights into various strategies used by FN teachers in raising awareness of NCDs among secondary school students. 


\section{Defining Non-Communicable Diseases (NCDs)}

NCDs refer to chronic diseases that could not be transferred from one individual to another, and these diseases typically progress slowly over a long period of time. The main types of NCDs include cardiovascular diseases (such as heart attack and stroke, cancers, chronic respiratory diseases and diabetes. These diseases are caused by a number of factors that includes ageing, fast and unplanned urbanisation, and the globalisation of unhealthy lifestyles (World Health Organisation, 2015). All age groups including children, adults, and the elderly around the world are vulnerable to the risk factors that contribute to NCDs.

Effective preventive and control strategies are vital to combat the incidence of NCDs. Managing these diseases requires a lot of funding due to expensive costs of diagnosis and treatment. Brunei Darussalam's Ministry of Health (2014) stated that the nation is genuinely concerned with issues pertaining to NCDs, because these issues had placed a significant burden on the nation's socio economic development. As a result, the Brunei Darussalam National Multi-Sectoral Action Plan for the Prevention and Control of NCDs (BruMAP-NCD 2013-2018) was launched in September 2013. This is an important step in enforcing relevant measures throughout the country. All of these measures are aimed at reducing the rate of premature death caused by NCDs with a target rate of $18 \%$ by 2018 . In order to achieve the target rate, six (6) key areas were identified and implemented such as: (i) to reduce tobacco use; (ii) promoting healthy and balanced diets; (iii) increase physical activities; (iv) identifying and managing people at risk with NCDs; (v) and finally, enhancing quality of care and managing outcome of NCDs (Piri, 2014). This paper focuses on the second area, namely, promoting healthy and balanced diets through education. Early introduction to healthy eating habits and food preferences, particularly in school, would improve long-term eating pattern and promote healthy lifestyle behaviours. Raising awareness among specific target groups in society, specifically the youth, students, senior citizens and people with NCDs, therefore, is very important. Nevertheless, effective preventive and control strategies require a holistic, incorporated, and multilevel method, warranting strong and sustained commitment and actions from all division to address NCDs (Ismail \& Koh, 2014).

\section{Methodology}

This study adopted a qualitative approach to research. Data were collected and triangulated consistently through observations, informal interviews and analysis of teachers' lesson plans as well as students' work. The first author of this paper conducted the research in all five participating schools. In this paper, findings obtained from lesson observations are reported to illustrate the kind of teaching strategies used by the participants to raise awareness of NCDs in all research sites.

Lesson observation was the main instrument for collecting data in the study. Nevertheless, the authors of this paper took note that further methodological improvements could have been made to the research design of the study. For example, to include a stratified testing sample (such as distributing survey questionnaires to teachers and / or students to assess the necessity of amending curricular setup to yield desired output) as a source of concrete assessment.

Lesson observations were carried out from May 2015 to August 2015, aimed at investigating teaching strategies used by FN teachers to raise awareness of NCDs among secondary school students. At least three lesson observations per class for each participating teacher in the study. During each lesson observation, field notes on the teachers' and students' activities were taken. Several aspects of teaching and learning were noted during lesson observations, and these include aspects such as: (i) the frequency of questionings (taking into consideration the type of questions asked, for example, lower-order or higher-order questions based on Bloom's Taxonomy) on NCDs; (ii) the students' correct answers; (iii) on task discussions on NCDs; (iv) inclusion of activities such as project work, pictorial, videos, and others by incorporating $21^{\text {st }}$ century skills (as outlined in the 21CLD rubrics); and finally, (v) checking for signs of students' motivation, understanding and engagement 
in the activities. Lesson observations also included the classroom ambience or environment. For example, the conduciveness of the FN classrooms and the availability of NCDs-related posters / leaflets / newspaper clippings in each of the classrooms observed were noted. The researchers used a set of observation checklist to record classroom incidences for each lesson.

\section{Research Sites}

The study was conducted in five government secondary schools in Brunei. These schools were purposefully selected as each offers FN as an option subject. Furthermore, each of the participating teachers in the study worked in each of the selected schools.

\section{Participants}

A total of five FN teachers were purposively selected as the participants of this study. Table 1 outlines the details of participating teachers in the study. The participants were regarded as exemplary teachers based on the results obtained by their students in the Brunei-Cambridge General Certificate of Education 'Ordinary' Level (BC-GCE ' $\mathrm{O}$ ' Level) for the past three years achieving $80 \%$ and above. In addition, a total of twenty-five students (five boys and twenty girls) participated in the study.

Table 1 Details of Participating Teachers in the Study

\begin{tabular}{llll}
\hline Participants & Gender & $\begin{array}{l}\text { Years of } \\
\text { Teaching FN }\end{array}$ & Educational Background \\
\hline Teacher A & Female & 11 years & $\begin{array}{l}\text { Diploma in Consumer Science } \\
\text { and Technology; Diploma in } \\
\text { Home Economic Education; BSc } \\
\text { (Hons) Food and Consumer } \\
\text { Science }\end{array}$ \\
\hline Teacher B & Female & 12 years & BEd General Science \\
\hline Teacher C & Male & 11 years & $\begin{array}{l}\text { BSc (Hons) Food Science and } \\
\text { Technology }\end{array}$ \\
\hline Teacher D & Female & 10 years & \begin{tabular}{l} 
HND Food Technology \\
\hline Teacher E
\end{tabular} \\
& Female & 5 years & $\begin{array}{l}\text { Diploma in Consumer Science } \\
\text { and Technology; Diploma in } \\
\text { Home Economic Education }\end{array}$ \\
\hline
\end{tabular}

In addition to gathering information of the teachers' teaching strategies, the researchers were also interested in identifying features of $21^{\text {st }}$ century lessons, specifically Collaboration and Knowledge Building. As reference, the researchers used two $21^{\text {st }}$ Century Learning Design (21CLD) rubrics produced by SRI International to identify the features of collaborative lessons and opportunities for knowledge building. Figure 1 shows the rubric for Collaboration and Figure 2 illustrates the rubric for Knowledge Building. 


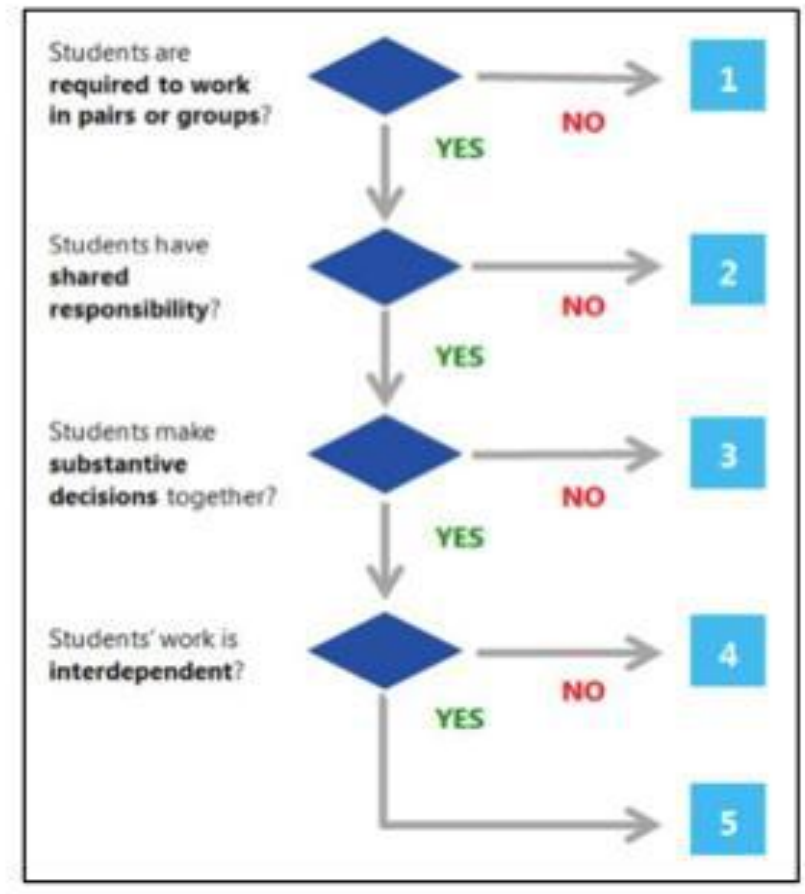

Figure 1. 21CLD Rubric for Collaboration

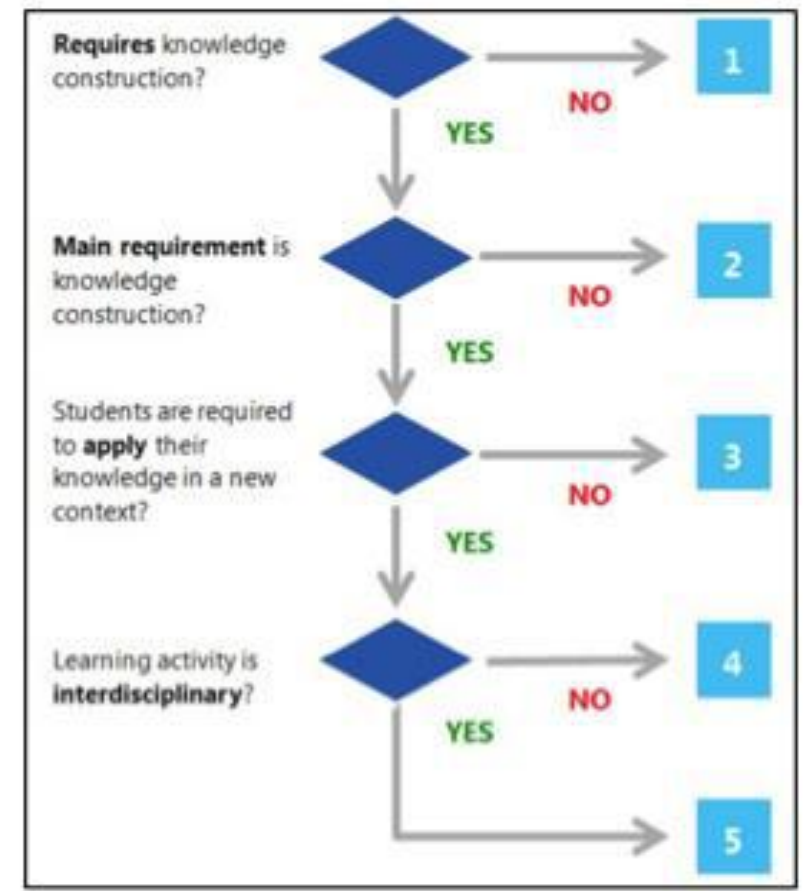

Figure 2. 21CLD Rubric for Knowledge Construction 


\section{Results and Discussion}

There were generally two categories of teaching strategies used by FN teachers in the study. These teaching strategies were categorized into: (i) traditional teacher-centred; and (ii) student-centred teaching strategies. All FN teachers in the study used traditional teacher-centred teaching strategies to teach proper dietary intake to prevent NCDs. All participating teachers were aware of student-centred teaching strategies and most of them made efforts to incorporate these strategies in their lessons, except one teacher. Table 2 outlines the teaching strategies used by the teachers in further detail.

Table 2 The Different Teaching Strategies Used By FN Teachers

\begin{tabular}{|c|c|c|c|c|c|}
\hline \multirow[t]{2}{*}{ Teacher } & \multicolumn{2}{|c|}{ No. of students } & \multirow{2}{*}{$\begin{array}{l}\text { Total } \\
\text { no. of } \\
\text { students }\end{array}$} & \multicolumn{2}{|c|}{ Teaching Strategies } \\
\hline & Boys & Girls & & $\begin{array}{l}\text { Traditional } \\
\text { Teacher-Centred }\end{array}$ & Student-Centred \\
\hline A & 2 & 4 & 6 & $\begin{array}{l}\text { Lecture and Note } \\
\text { Reading } \\
\text { Observation }\end{array}$ & $\begin{array}{l}\text { Experiential Learning } \\
\text { Collaborative Learning } \\
\text { Discussion using audio- } \\
\text { visual }\end{array}$ \\
\hline B & 0 & 4 & 4 & $\begin{array}{l}\text { Lecture and Note } \\
\text { Reading }\end{array}$ & None \\
\hline $\mathrm{C}$ & 2 & 4 & 6 & $\begin{array}{l}\text { Lecture by Note Reading } \\
\text { Observation }\end{array}$ & $\begin{array}{l}\text { Experiential and Inquiry- } \\
\text { Based Learning } \\
\text { Collaborative Learning }\end{array}$ \\
\hline $\mathrm{D}$ & 0 & 6 & 6 & $\begin{array}{l}\text { Lecture by Note Reading } \\
\text { Observation }\end{array}$ & $\begin{array}{l}\text { Experiential Learning } \\
\text { Collaborative Learning }\end{array}$ \\
\hline $\mathrm{E}$ & 1 & 2 & 3 & $\begin{array}{l}\text { Lecture by Note Reading } \\
\text { Observation }\end{array}$ & Inquiry-Based Learning \\
\hline
\end{tabular}

Each of the teaching strategies is discussed next. The discussion will start with traditional teacher-centred strategies followed by those categorized as student-centred strategies. Based on the first author's observation, all participating teachers delivered lectures and provided students with a lot of information through typed notes using Microsoft Word or Microsoft Power-point presentations. The first author also noted frequent 'simple question and answer' sessions during lectures. The term 'simple question and answer' here means, that the teacher merely asked students to highlight keywords in their handouts and write extra notes on a piece of paper. In addition to using handouts or notes during lectures, the first author noted other techniques such as mind-maps or concept mapping. For example, Teacher $\mathrm{C}$ used mind-maps to illustrate key concepts during a lecture. As shown in Figure 3, Teacher $\mathrm{C}$ used mind-mapping technique to create a visual diagram that represented all of the interrelated factors leading to NCDs. 


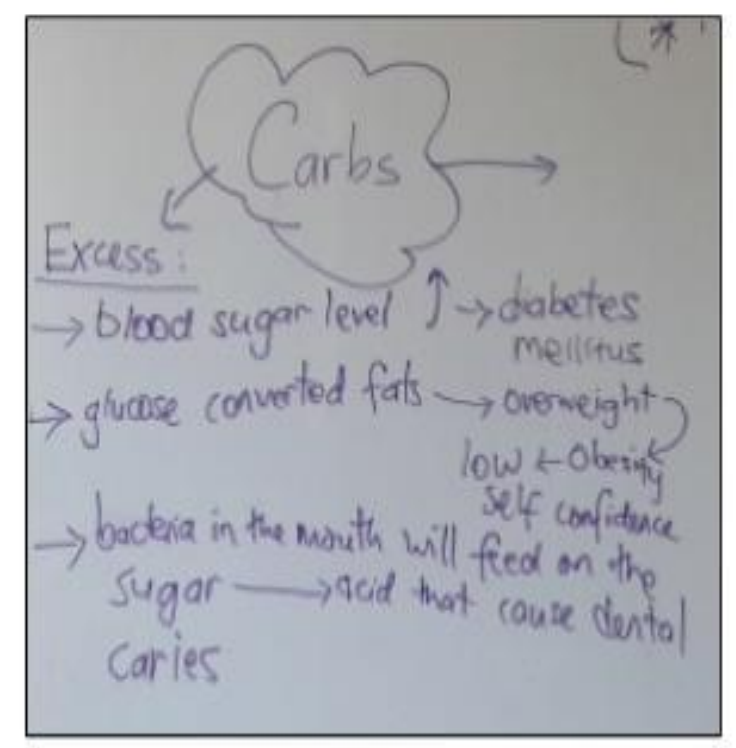

Figure 3. Mind-mapping done by Teacher C during Lecture

It was observed that most of the students paid attention to their teachers' lectures. The students actively posed questions comprising mainly lower-order questions during lectures. Some examples of these questions include: "What happens when people drink Coke?" "What are the symptoms of a person having hypertension?". It was also noted that most teachers in the study started their questions with how (describe), what and why, and these questions could be categorized as remembering, understanding and applying respectively (in the three lowest levels of Bloom's taxonomy). Some examples of these questions include: "What can we do to prevent CHD?" "In what ways do we reduce fats / lipids intake in our diet?" "Why do we need to cut down salt in cooking or foods?" "Give examples of what Bruneians like to eat nowadays."

Only two teachers made efforts to use experiential learning in their lessons. Teacher A introduced the use of an electronic sphygmomanometer to measure blood pressure and heart beat in one of her activities. She prepared a set of questions for the 'measuring blood pressure and heart beat' activity and the students were divided into two groups to answer the questions. This activity encouraged the students to work collaboratively with each other. Figure 4 shows the worksheet that the students completed during this lesson. 


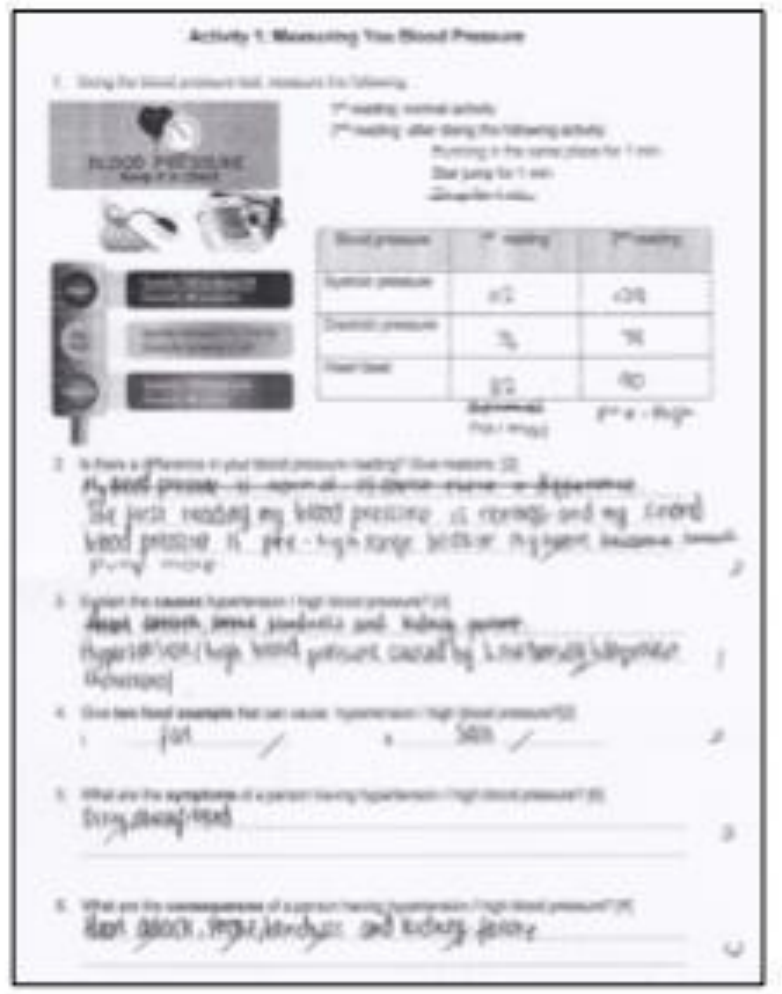

Figure 4. Measuring Blood Pressure and Heart Beat Activity Sheet

Through this activity, students had the opportunity to use actual sphygmomanometer and learned about high blood pressure (also known as hypertension) in depth. In doing so, students were able to relate systolic and diastolic measurements to the definition of hypertension.

In another FN lesson, Teacher D provided an opportunity for the students to apply what they have learned about reducing the amount of fat and salt in our food by making a healthy egg sandwich. Teacher D commenced the lesson by reminding students about rules and regulations (pertaining to hygiene and safety) that we need to keep in mind before preparing our food in the kitchen such as wearing clean apron, keeping short fingernails and washing hands regularly. Then, Teacher D introduced the healthier choice of ingredients to students, which included wholemeal bread, low fat mayonnaise, less salt, boiled eggs, avocado, spring onions, and two other types of vegetables. Next, Teacher D proceeded with the preparation of sandwich by mashing the boiled eggs, slicing the vegetables, mixing the mayonnaise aith a little bit of salt. While preparing the ingredients, Teacher D carried out a simple question and answer session on reasons for and the benefits of reducing the intake of fat and salt in our food. After demonstrating the process of making a healthy sandwich, Teacher D instructed the students to make their own version of a healthy egg sandwich. Teacher D encouraged the students to be creative with their recipes.

Another example of teaching strategy that could be categorized as student-centred was the use of inquiry-based learning where the teacher asked students to conduct online research on Dietary Recommendations and present their findings to the class. A teacher in School C used this strategy to encourage the students become independent learners and work collaboratively to attain the learning goal. The students were divided into two groups and each group came up with their own research and presentation strategies. As a result of this activity, each group produced Power-point slides for their respective presentations to the class. Figure 5 illustrates the Power-point slides produced by one of the groups. 

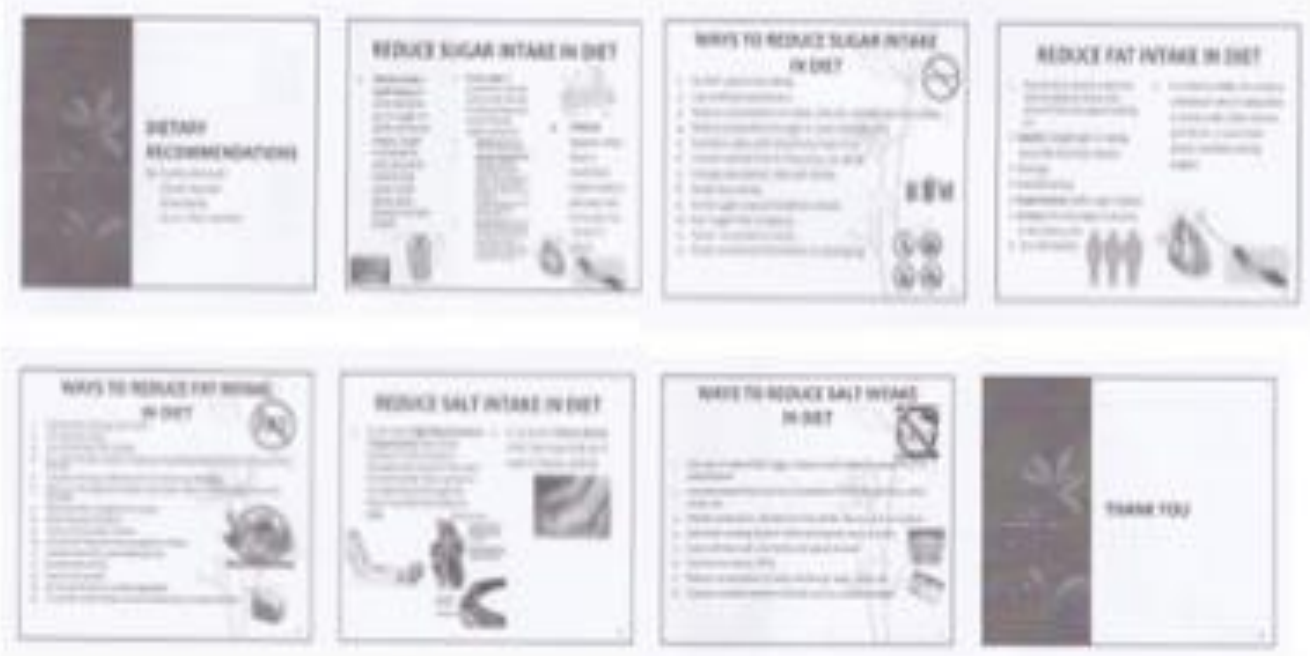

Figure 5. Presentation Slides by Students from School C

Both groups presented their findings and every member participated during each presentation. The teacher was very pleased with the students' efforts and findings, and both groups received positive feedback from the teacher. Another teacher in another school also made an effort to incorporate inquiry-based learning in her teaching. Similar to the teacher in School C, Teacher E asked her students to find out about selected NCDs, specifically: obesity, diabetes and cancer. The students were given a week to complete the task and present their findings in the next class. Figure 6 shows some of the students' notes during their research.

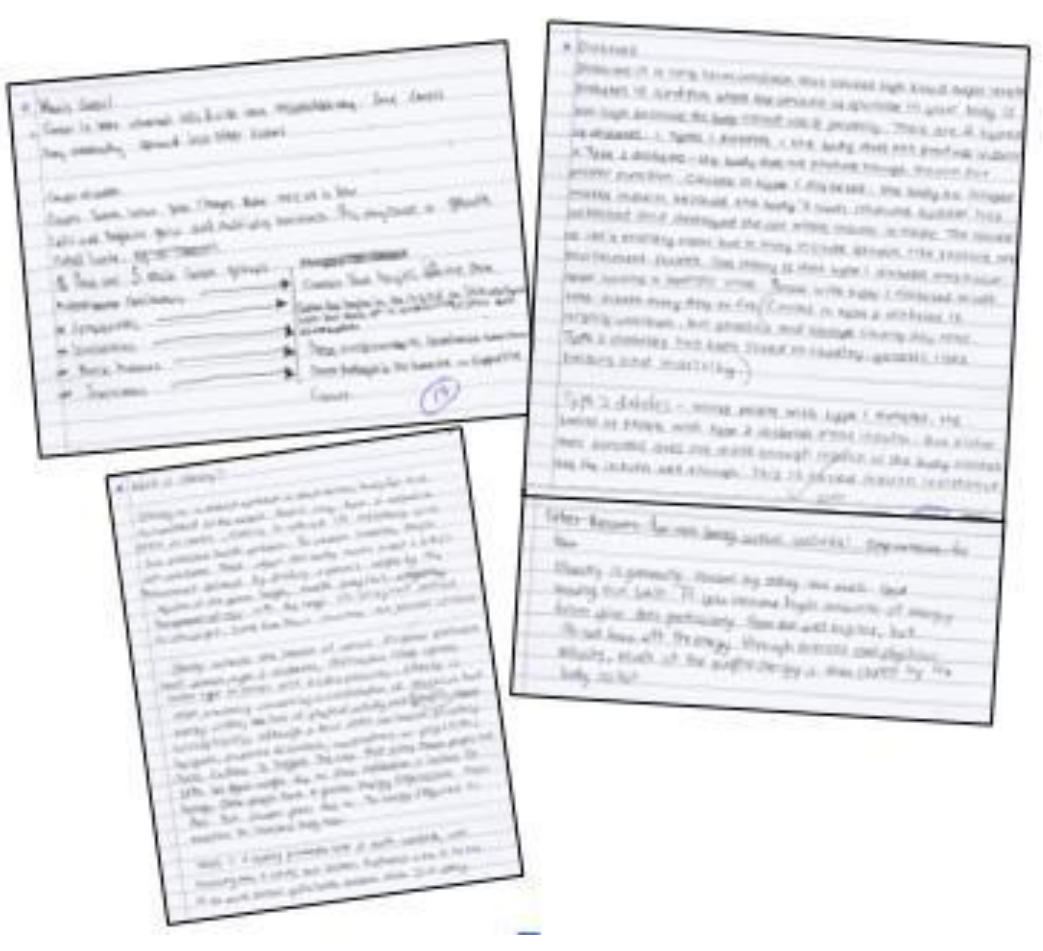

Figure 6. Students' Notes on Selected NCDs 
Noormah Azrayati Haji Mohammad Noor and Jainatul Halida Jaidin / Teaching Strategies To Raise Awareness of Non-Communicable Diseases in Secondary Schools in Brunei Darussalam

\section{How Effective Are These Teaching Strategies in Raising Awareness of NCDs?}

The effectiveness of these teaching strategies was analysed using the teachers' lesson plans and the students' work. The teachers' intended learning outcomes were compared with actual work produced by the students. Marks obtained by the students in each of the activities were collected and served as evidence in measuring the effectiveness of the teaching strategies. Overall, the students obtained high marks in most activities. This suggests that the strategies were effective in delivering basic and challenging contents of the topic, more specifically in getting the students to recall, remember and analyse information about dietary factors contributing to NCDs.

Table 3 Students' Marks in School A

\begin{tabular}{l|l|l|l|l}
\hline $\begin{array}{l}\text { Name of } \\
\text { students }\end{array}$ & \multicolumn{4}{|c}{ Marks Obtained } \\
\cline { 2 - 5 } & $\begin{array}{l}\text { Activity 1 } \\
\text { Basic Questions } \\
\text { on Diabetes }\end{array}$ & $\begin{array}{l}\text { Activity 2 } \\
\text { Basic } \\
\text { Questions on } \\
\text { Reducing the } \\
\text { Amount of Fat } \\
\text { and Salt in } \\
\text { Our Food }\end{array}$ & $\begin{array}{l}\text { Activity 3 } \\
\text { Basic Questions } \\
\text { on Cholesterol }\end{array}$ & $\begin{array}{l}\text { Activity 4 } \\
\text { Challenging } \\
\text { Questions on Blood } \\
\text { Pressure }\end{array}$ \\
\hline & Full Mark & Full Mark & Full Mark & \\
\hline & 10 & 26 & 21 & Full Mark \\
\hline Student A & 5.5 & 19 & 21 & 18 \\
\hline Student B & 4 & 21.5 & 9 & 8 \\
\hline Student C & 6 & 24.5 & 21 & 7 \\
\hline Student D & 4 & 21 & 21 & 6 \\
\hline Student E & 3 & 22 & 21 & 7 \\
\hline Student F & 6 & 23 & 20 & 11 \\
\hline
\end{tabular}

Table 3 outlines the marks obtained by students in School A. In this school, the students managed to score good marks in Activity 1, Activity 2 and Activity 3. However, only two students managed to score passing marks in Activity 4. In this activity, the students were required to answer challenging questions on Blood Pressure. It was interesting to note that the teaching strategy used for Activity 4 was both experiential and collaborative learning, wherein an actual instrument to measure blood pressure was used by the students to complete the given worksheet. Based on the first author's observation of the lesson, the students were on-task throughout the activity and they enjoyed the hands-on experience of measuring blood pressure and heartbeats. A more in-depth investigation is required to shed light on what worked and what did not work with this particular strategy.

Table 4 outlines marks obtained by all participating students in School B. As can be seen in Table 4, the students scored highly in both activities involving lower-order thinking.

\section{Table 4 Students' Marks in School B}

\begin{tabular}{l|l|l}
\hline \multirow{2}{*}{$\begin{array}{l}\text { Name of } \\
\text { students }\end{array}$} & \multicolumn{2}{c}{ Marks Obtained } \\
\cline { 2 - 3 } & $\begin{array}{l}\text { Activity 1 } \\
\text { Basic Questions on Reducing the } \\
\text { Intake of Sugar in Our Food }\end{array}$ & $\begin{array}{l}\text { Activity 2 } \\
\text { Comprises of Low Order Questions on } \\
\text { Reduce intake of fat }\end{array}$ \\
\hline & $\begin{array}{l}\text { Full Mark } \\
\end{array}$ & $\begin{array}{l}\text { Full Mark } \\
18\end{array}$ \\
\hline Student A & 8 & 18 \\
\hline Student B & 7.5 & 18 \\
\hline Student C & 7 & 17.5 \\
\hline Student D & 6.5 & 18 \\
\hline
\end{tabular}


In School C, all participating students in School C managed to score passing marks in an activity that posed challenging questions about dietary factors leading to NCDs. Table 5 outlines the students' marks. In this activity, the inquiry-based learning strategy helped the students develop a better understanding about Dietary Recommendations to prevent NCDs.

Table 5 Students' Marks in School C

\begin{tabular}{l|l}
\hline Name of students & \multicolumn{1}{c}{ Marks Obtained } \\
\cline { 2 - 2 } & $\begin{array}{l}\text { Activity 1 } \\
\text { Challenging Questions on Reducing the Intake of Fat, Salt and } \\
\end{array}$ \\
& Sugar (Dietary Recommendations) \\
& Full Marks \\
\hline Student A & 15 \\
Student B & 18 \\
Student C & 15 \\
Student D & 15 \\
Student E & 18 \\
Student F & 18 \\
\hline
\end{tabular}

Based on the first author's observations, the students worked collaboratively when analysing and evaluating relevant information for their presentations. They brainstormed, discussed, argued and eventually agreed on a final set of information and presentation layout.

In School D, all students managed to obtain very good marks for both activities. Table 6 outlines the marks obtained by the students in this school. Teaching strategies used by the FN teacher in this school were effective in helping the students understand the benefits of reducing fat, salt and sugar in our diet.

Table 6 Students' Marks in School D

\begin{tabular}{l|l|l}
\hline Name of & \multicolumn{2}{|c}{ Marks Obtained } \\
\cline { 2 - 3 } students & $\begin{array}{l}\text { Activity 1 } \\
\text { Basic Questions on Reducing the } \\
\text { Intake of Fat, Salt and Sugar } \\
\text { (Dietary Recommendations) }\end{array}$ & $\begin{array}{l}\text { Activity 2 } \\
\text { Making a Healthy Egg Sandwich }\end{array}$ \\
& \multicolumn{2}{|c}{ Full Marks } \\
& 12 & 25 \\
\hline Student A & 10 & 20 \\
Student B & 11 & 22 \\
Student C & 12 & 21 \\
Student D & 12 & 22 \\
Student E & 11 & 23 \\
Student F & 11.5 & 23 \\
\hline
\end{tabular}

Figure 7 shows a student's answer sheet for Activity 1 in School D and this suggests that the teaching strategy used by the teacher as effective in delivering the lesson. 


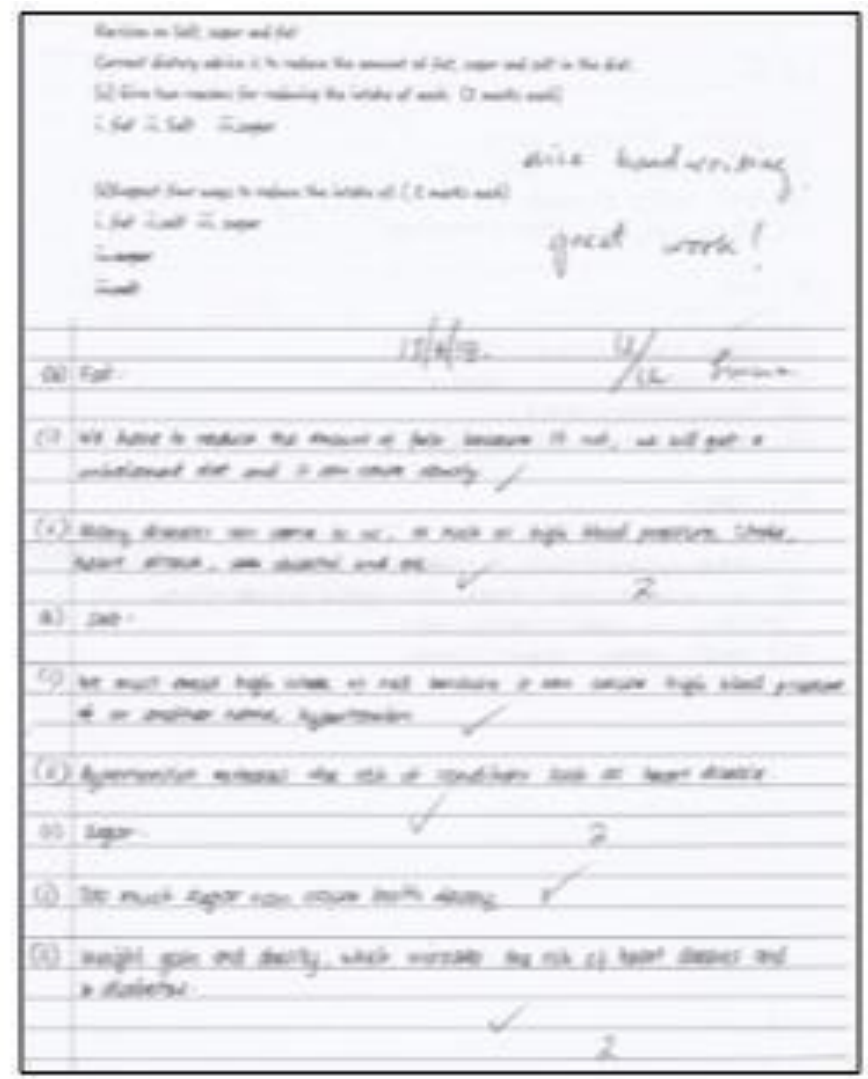

Figure 7. A Student's Answer Sheet fro Activity 1 in School D

Table 7 outlines the three activities in School E. All students in this school managed to score good marks in all activities, except Student A in Activity 3, as the student was absent on that day.

Table 7 Students' Marks in School E

\begin{tabular}{l|l|l|l}
\hline \multirow{2}{*}{$\begin{array}{l}\text { Name of } \\
\text { students }\end{array}$} & \multicolumn{3}{|c}{ Marks Obtained } \\
\cline { 2 - 4 } & $\begin{array}{l}\text { Activity 1 } \\
\text { Research - Cancer, } \\
\text { Obesity and Diabetes }\end{array}$ & $\begin{array}{l}\text { Activity 2 } \\
\text { Pop Quiz (on selected } \\
\text { NCDs and diet) }\end{array}$ & $\begin{array}{l}\text { Activity 3 } \\
\text { Basic Questions on } \\
\text { Tooth Decay and } \\
\text { Reducing Intake of } \\
\text { Sugar }\end{array}$ \\
& & & Full Marks \\
& & & 12 \\
\hline & 20 & 15 & ABSENT \\
& & 12 & 11 \\
Student A & 13 & 12.5 & 4 \\
Student B & 15 & 11.5 & \\
Student C & 13 & & \\
\hline
\end{tabular}

\section{Conclusion}

The current study presents a variety of teaching strategies used by FN teachers to raise awareness of NCDs among secondary schools in Brunei Darussalam. The teaching strategies were generally effective in helping students understand the long-term benefits of lowering the intake of fat, salt and sugar in our diet. However, the findings of this study also suggest that there is a need for FN teachers to provide more opportunities for the 
Noormah Azrayati Haji Mohammad Noor and Jainatul Halida Jaidin / Teaching Strategies To Raise Awareness of Non-Communicable Diseases in Secondary Schools in Brunei Darussalam

students to analyse current dietary issues in the country and suggest solutions to address these issues. For example, FN teachers can start with getting the students to reflect on their own daily dietary intakes and create a meal plan that is healthier for themselves and the family.

\section{References}

Al-Nohair, S. (2014). Obesity in Gulf Countries. International Journal of Health Sciences, 8(1), pp. 79-83.

Ball, L. E., Hughes, R. M., \& Leveritt, M. D. (2010). Nutrition in general practice: role and workforce preparation expectations of medical educators, Australian Journal of Primary Health, 16(4), pp. 304-310.

Baumbusch, J. (2010). Semi-structured interviewing in Practice-Close Research. Journal for Specialists in Pediatric Nursing, 15(3), pp. 255-258.

Borbasi, S., Chapman, Y., Gassner, L., Dunn, S., \& Read, K. (2002). Perceptions of the researcher: In-depth interviewing in the home. Contemporary Nurse, 14, pp. 24-37.

Carraway-Stage, V., Henson, S. R., Dipper, A., Spangler, H., Ash, S. L., and Goodell, L. S. (2014). Understanding the state of nutrition education in the head start classroom: A qualitative approach. American Journal of Health Education, 45, pp. 52-62, DOI:10.1080/19325037.2013.853000

Cheng, N. Y. I., \& Wong, M. Y. E. (2015). Knowledge and attitude of school-teachers towards promoting healthy lifestyle to students. Health, 7(01), p. 119. Retrieved from http://www.scirp.org/journal/PaperInformation.aspx?paperID=53318\#.VTGaWiGeDGc

Contento, I. R. (2007). Nutrition education: linking research, theory, and practice. UK: Jones \& Bartlett Learning.

Creswell, J. W. (2014). Qualitative, quantitative, and mixed methods approaches research designs ( ${ }^{\text {th }}$ Ed.). USA: SAGE Publications.

Denman, S. (1999). Health promoting schools in England - A way forward in development. Journal of Public Health, 21(2), pp. 215-220, DOI: 10.1093/pubmed/21.2.215

Dimitrios, B., Labros, S., Nikolas, K., Maria, K., \& Athanasios, K. (2013). Traditional teaching methods vs. teaching through the application of information and communication technologies in the accounting field: Quo Vadis?. European Scientific Journal, 9(28).

Driscoll, D. L. (2011). Introduction to primary research: Observations, surveys, and interviews. Writing Spaces: Readings on Writing, 2, pp. 153-174.

Drummond, C. E. (2010). Using nutrition education and cooking classes in primary schools to encourage healthy eating. Journal of Student Wellbeing, 4(2), pp. 43-54.

Güngör, N. K. (2014). Overweight and obesity in children and adolescents. Journal Clinical Research in Pediatric Endocrinology, 6, pp. 129-143, DOI: 10.4274/jcrpe.1471

Hackathorn, J., Solomon, E. D., Blankmeyer, K. L., Tennial, R. E., \& Garczynski, A. M. (2011). Learning by doing: An empirical study of active teaching techniques. The Journal of Effective Teaching, 11(2), pp. 40-54.

Harrell, M. C., \& Bradley, M. A. (2009). Data collection methods semi-structured interviews and focus groups. Santa Monica, CA: Rand National Defense Research Institute.

Hawkes, C. (2013). Promoting healthy diets through nutrition education and changes in the food environment: An international review of actions and their effectiveness. Retrieved on September 1, 2015 from http://www.fao.org/docrep/017/i3235e/i3235e.pdf

Ismail, P. K. P., \& Koh, D. (2014). Role of occupational health in managing non-communicable diseases in Brunei Darussalam. Global Health Action. Retrieved on September 1, 2015 from http://www.ncbi.nlm.nih.gov/pmc/articles/PMC4224701/

Kauchak, D., \& Eggen, P. (2012). Learning \& teaching research-based methods $\left(6^{\text {th }}\right.$ Ed.). UK: Pearson.

Knowledge Convention Report (2012). Majlis Ilmu 2012: Nikmat kesihatan asas kesejahteraan Negara. Brunei International Medical Journal, 8(5), pp. 283-288.

Martin, A., Saundrs, D. H., Shenkin, S. D., \& Sproule, J. (2014). Lifestyle intervention for improving school achievement in overweight or obese children and adolescents. Cochrane Database of Systematic Reviews, (3), DOI: 10.1002/14651858.CD009728.pub2. 
Ministry of Education (2011). School Based Assessment for Learning Brunei Darussalam: SBAfL, Guidebooks for Year 7 and 8 Core Subjects. Ministry of Education, Brunei Darussalam: Curriculum Development Department.

Ministry of Education (2013). The National Education System for the 21st Century: SPN21 (Revised Ed.). Ministry of Education, Brunei Darussalam.

Ministry of Health (2013). Brunei Darussalam National Multisectoral Action Plan for the Prevention and Control of Noncommunicable Diseases (BruMAP-NCD) 2013-2018. Retrieved on September 1, 2015 from http://www.moh.gov.bn/download/download/BRUMAPBOOK.pdf

Musaiger, A. O., \& Al-Hazzaa, H. M. (2012). Prevalence and risk factors associated with nutrition-related noncommunicable diseases in the Eastern Mediterranean region. International Journal of General Medicine, 5, pp. 199-217, DOI: 10.2147/IJGM.S29663

Parasuram, R., Huiting, X., Wang, J., Thirumarban, A., Joon, K. E., \& Poh, C. L. (2014). Effectiveness of using non-traditional teaching methods to prepare student health care professionals for the delivery of the mental state examination: A systematic review protocol. The JBI Database of Systematic Reviews and Implementation Reports, 12(8), pp. 3-19, DOI:10.11124/jbisrir-2014-1354.

Plaxcedia, M. (2015). Strategies for enhancing teaching of food and nutrition in future urban secondary schools, Manicaland Province. IOSR Journal of Research \& Method in Education, 5(1), pp. 75-83, DOI:10.9790/738805117583

Peck, A. C., Ali, R. S., Matchock, R. L., \& Levine, M. E. (2006). Introductory psychology topics and student performance: Where's the challenge? Teaching of Psychology, 33(3), pp. 167-170.

Prince, M. (2004). Does active learning work? A review of the research. Journal of Engineering Education, 93(3), pp. 223-231.

Russell, A. T., Comello, R. J., and Wright, D. L. (2007). Teaching strategies promoting active learning in healthcare education. Journal of Education and Human Development, 1(1), pp. 1-8.

Shah, P., Misra, A., Gupta, N., Hazra, D. K., Gupta, R., Seth, P., \& Goel, K. (2010). Improvement in nutritionrelated knowledge and behaviour of urban Asian Indian school children: Findings from the 'Medical Education for Children / Adolescents for Realistic Prevention of Obesity and Diabetes and for Healthy Ageing'(MARG) Intervention Study'. British Journal of Nutrition, 104(03), pp. 427-436.

Singura, L. (2013). Impact of Nutrition Education on Student Learning. Unpublished Doctoral Dissertation. Minnesota, USA: Walden University.

Sovyanhadi, M., \& Cort, M. A. (2004). Effectiveness of various nutrition education teaching methods for high school students: A case study in Alabama, United States. Malaysian Journal of Nutrition, 10(1), pp. 31-37.

Umer, S. \& Siddiqui, J. A. (2013). Improving trends of teaching methods used in the Concept Schools of Karachi: An evaluative study. Journal of Educational Research International, 2(2).

Vygotsky, L. (1978). Mind in society: The development of higher development of higher psychological process. Cambridge, MA: Harvard University Press.

Wandberg, R. \& Rohwer, J. (2010). Teaching health education in language diverse classrooms. USA: Jones and Bartlett Publisher.

World Health Organisation (2015). Noncommunicable Diseases. Retrieved on September 1, 2015 from http://www.who.int/mediacentre/factsheets/fs355/en/ 